\title{
Mistaken Identities: The Media and Parental Ethno-Religious Socialization in a Midwestern Sikh Community
}

\author{
Meenal Rana ${ }^{1, *}$, Desiree B. Qin ${ }^{2}$ and Carmina Vital-Gonzalez ${ }^{3}$ \\ 1 Child Development, Humboldt State University, Arcata, CA 95521, USA \\ 2 Human Development and Family Studies, Michigan State University, East Lansing, MI 48823, USA; \\ qindesiree@gmail.com \\ 3 Psychology, California State University Chico, Chico, CA 95929, USA; cvital@mail.csuchico.edu \\ * Correspondence: meenal.rana@humboldt.edu
}

Received: 24 July 2019; Accepted: 30 September 2019; Published: 12 October 2019

\begin{abstract}
Strong anti-Islamic sentiments increased dramatically after the 9/11 terror attacks on the United States, leading to an uptick in prejudice and the perpetration of hate crimes targeting Muslims. Sikh men and boys, often mistaken for Muslims, suffered as collateral damage. The overall health of both communities has been adversely affected by these experiences. Faced with such realities, communities and parents often adopt adaptive behaviors to foster healthy development in their children. In this paper, drawing on interviews with 23 Sikh parents from 12 families, we examine Sikh parents' ethno-religious socialization of their children. The confluence of media stereotyping and mistaken identities has shaped Sikh parents' beliefs regarding their children's retention/relinquishment of outward identity markers. Sikh parents, in general, are concerned about the safety of their boys, due to the distinctive appearance of their religious markers, such as the turban. They are engaged in a constant struggle to ensure that their children are not identified as Muslims and to protect them from potential harm. In most of the families in our study, boys were raised to give up wearing the indicators of their ethno-religious group. In addition, many parents took responsibility for educating the wider community about their ethno-religious practices through direct communication, participation in cultural events, and support of other ethno-religious minorities. Policy implications are discussed.
\end{abstract}

Keywords: parent ethno-religious socialization; mistaken identities; stereotypical media images; identity markers; Sikhism

\section{Introduction}

On a Sunday morning in August 2012, an American named Michael Page attacked a Gurdwara (Sikh temple) in Oak Creek, Wisconsin. He killed five men and one woman; all five male victims were wearing their turbans, an integral part of their religious faith (Gast 2012). In another incident a turban-wearing New Yorker, Sandeep Singh, was run over by a pickup truck. The driver, Joseph Caleca, called Singh a "terrorist" after dragging him for some distance with his vehicle (Dubensky 2015). In a more recent incident, a gunman shot a Sikh man in Kent, Washington (Le 2017). Similar hate crimes against Sikhs have proliferated since 9/11.

Since the election of President Trump, Islamophobia and anti-immigrant bigotry, fear, hatred, and otherization have intensified (Sunar 2017). The role of the media in constructing the stereotypical portrayal of Muslims and the effects of that image on Muslim communities in the United States have been well reported (Abbas 2004). Moreover, the portrayal of Muslims in popular media has intensified stereotypical images of several other ethno-religious groups in the United States, among them Sikhs 
(Ahluwalia and Pellettiere 2010; Kromidas 2004; Kumar 2016). The influence of popular media in stigmatizing ethno-religious minority families and their socialization practices is an understudied phenomenon. Superficial understanding of intergroup differences often gives rise to misidentification of minorities on the basis of appearance alone. In the United States, the media often mistakes Sikh men and boys for Muslims because of perceived similarities in their appearance (e.g., turbans and beards). The physical and mental health of both Muslim and Sikh communities have suffered similarly (Ahluwalia and Pellettiere 2010; Kumar 2016). A 2013 survey conducted by The Pluralism Project (2013) at Harvard University shows that since $9 / 11$ about $83 \%$ of Sikhs have either experienced hate crimes or known someone who has fallen victim to bigotry. A study conducted by The Sikh Coalition (2014) shows that $50 \%$ of Sikh children are bullied at school; when the sample is restricted to practicing Sikhs who wear turbans, the number is even higher (67\%).

Nevertheless, few studies have examined how Sikh immigrant communities and families deal with the elevated hostility and discrimination engendered by prejudicial representation in popular media. In addition to its contribution to existing research on immigrant parent socialization, more specifically ethno-religious socialization and discrimination, our study adds to the scant body of research on the role of popular media in stereotyping certain groups and creating "otherization." More importantly, our study acknowledges that popular media plays an important role in Sikh families' parental ethno-religious socialization. The turban worn by Sikh men, one of the articles of their faith, is particularly implicated in the aforementioned problem of misidentification. The turban has deep-rooted historic and religious significance for Sikh men; they believe it is a gift from their Gurus, and wear it as an assertion of equality among all people. It also represents faithfulness to the Sikh values of service, compassion, and justice (Guru Nanak Mission 2008). In the face of multiple pressures-globalization, individual choice, societal pressure, and religious prejudice-Sikh men and boys must consciously decide whether or not to continue wearing their turbans. The former option does not necessarily constitute alienation from the deep-rooted spiritual values of the religion, but is instead an adapted form of religiosity. This paper focuses on the role of stereotyping and mistaken identity in Sikh parents' ethno-religious socialization of their children, particularly with regard to boys, who are more prone to misidentification and more often than not prioritized within traditional families. Since boys and men are more vulnerable to bullying and discrimination due to their outward identity markers, the focus of this study was ethno-religious socialization of boys.

\subsection{The Sikh Community in the United States}

There have been three waves of Sikh immigration to the United States: (1) Farm laborers and railroad workers migrated to California in the 1800s; (2) post-1965 Hart-Cellar Act new immigrants, seeking higher education and family reunification; and (3) asylum seekers, who came in the late 1980s and early 1990s following the Hindu-Sikh riots in India (Crossette 2004). The vast majority of Sikh immigrants to the United States come from India (Mann 2006). There are currently approximately 280,000 Sikhs in the United States, accounting for $10 \%$ of all Asian Indians (The Association of Religious Data Archives 2010). According to the American Sikh Organization, this number could, in fact, be as large as 500,000 (Pew Forum 2012). The majority of Sikhs speak Punjabi as their first language. Similar to many other immigrant groups in the United States, Sikhs have put down roots, built homes, established communities, demonstrated their patriotism by purchasing or leasing agricultural lands, and joined the military (Mann 2006). However, their integration into American culture has been fraught in some regards; certain workplaces, for example, prohibit head coverings, facial hair, jewelry, and weapons. The exterior markers of Sikh identity include long hair worn in a turban, a blunt sword, and a steel bracelet—symbolic representations of holiness, leadership, order, justice, protection for the weak, strength, and integrity (Guru Nanak Mission 2008). After the 9/11 attacks, the turban was invoked in the racial profiling used by counter-terrorism surveillance technologies (Puar and Rai 2002). As a result of the ensuing problem of misidentification, Sikh 
communities have found support in collective practices that serve as antidotes to negative stereotypes (Ahluwalia and Pellettiere 2010; Kurien 2014).

The media-influenced marginalization of Sikh communities has been especially challenging for parents as they negotiate the ethno-religious socialization of their children. There is limited (and somewhat dated) research available on Sikh families and children: One notable example is Gibson (1989) study of Sikh American students' strong performance in schools despite their limited language abilities, cultural differences, and subjection to prejudice. Another study, which examined the immediate after-effects of 9/11 on Sikh youth in American schools, found that many Sikh students were altering their appearances in order to fit in with the mainstream (Verma 2005). A more recent qualitative phenomenological study examined how five Sikh men coped with the experiences of discrimination in New York City after 9/11 (Ahluwalia and Pellettiere 2010). Nonetheless, few studies have examined how Sikh immigrant families and communities engage in ethno-religious socialization with their children in view of media-generated stereotyping.

\subsection{Parental Racial/Ethno-Religious Socialization}

In addition to fostering individual child development, minority parents must socialize their children to construct and negotiate their ethnic identities across two or more cultures, languages, and often nations (García-Coll et al. 1996). The manner in which parents transmit information, values, and perspectives pertaining to ethnicity and race to their children is commonly referred to as ethnic or racial socialization (Hughes et al. 2006). Ethnic/racial socialization includes parental practices that promote cultural, racial, and ethnic pride; create mistrust of other groups; and prepare their children for potential racism. This socialization could be proactive or reactive, overt or covert, and initiated by children or parents (Hughes et al. 2006; Umaña-Taylor and Fine 2004). Proactive socialization involves preparing children for prejudice and discrimination they might encounter. Reactive socialization is the processing done with children after encounters with discriminatory behaviors. Parents may use direct messages such as "you should be proud to be a Sikh", i.e., overt socialization; or they may take them to Gurdwara (Sikh temple) to observe the community's various religious practices, i.e., covert socialization. These interactions may be initiated by children as well as by parents (Hughes et al. 2006). Parents may use modeling, encourage their children to attend church or temple, take them to community gatherings, supply relevant literature, tell stories about the history of their race and religion, and share advice about socializing their children (Hughes et al. 2006). Immigrant parents keep in touch with their extended family members in their home country-another means of maintaining their cultural ties (Ferguson et al. 2016).

Parents' ethnic/racial socialization of their children is affected by individual experiences of discrimination (Caughy et al. 2002), along with immigration history, current status in the host country, connections with home country, and social capital embedded in the community (Berry and Sam 1997; Okagaki and Bingham 2005; Yosso 2005). According to the integrative model of child development proposed by García-Coll et al. (1996), social constructs such as racism, discrimination, and oppression can promote adaptive parenting socialization strategies designed to help children cope with discrimination and bolster their self-image. Sikh parents must negotiate the conflict between their religious values (i.e., egalitarianism, fearlessness, and social justice) and the need to prepare their sons for fallout discrimination in the current Islamophobic environment. The safety of their children must be their top priority. Some ethno-religious considerations in Sikh families' socialization might include: Intergenerational relationships, the history of Sikhism, the acculturation gap between parents and children, sense of community, and role of extended family members in raising children. There are studies of ethnic and racial socialization in African American families and minorities such as Latino Americans (Hughes 2003; Romero et al. 2000; Umaña-Taylor and Fine 2004), Asian American families, and transracial adoptees (Yoon 2004). There is, however, a significant paucity of research on parental ethno-religious socialization practices in immigrant and minority families, more specifically 
Sikh families. The few studies on Asian Indian parents, for example, gloss over the Sikh community's identity as a separate ethnic group (Inman et al. 2007).

Differentiating between religion and ethnicity is often difficult. Often, parents socialize their children via religious practices, thus integrating religion into their ethnic identity. This paper hence considers the two variables as a single construct: Ethno-religious identity (Stout 1975). Sikh parents may want their children to internalize religious values (i.e., equality, service, social justice, fearlessness, strength, honesty) and cultural values (i.e., respect for elders, sharing food, etc.) at the same time. Oftentimes, the religious and cultural values are intertwined. For example, the value of sharing food is connected to service in Sikhism. The community lunch, langar, is thus an ethno-religious event. Similarly, the outward markers of Sikhism evidence cultural and religious integration. These markers are associated mainly with boys, who are traditionally viewed as transmitters of the religion to the next generation.

Drawing on Bronfenbrenner's bioecological framework (Bronfenbrenner 1979), we examine Sikh immigrant parents' ethno-religious socialization strategies given the Islamophobic environment, media-induced misidentification, and ethno-religious community support. We integrate parent socialization practices (Hughes et al. 2006) and adaptive parenting strategies (García-Coll et al. 1996) into the microsystem layer (i.e., innermost layer with proximal processes) of the model. We also examine how parenting strategies are affected by the parents' education, occupations, and personal ethno-religious experiences and identities. According to Bronfenbrenner, there are bidirectional processes within the microsystem: Family-driven socialization of the children, and youth-driven socialization of the parents (Umaña-Taylor et al. 2013). In this paper, we focus on the parents' point of view. At the macrolevel, we integrate the role played by popular media in stereotyping minorities, which might affect Sikh parents' ethno-religious socialization of their sons on both the familial and community levels (Matin et al. 2008).

The media have similarly affected African American parental socialization of their sons. Studies show that their priority is to protect their sons from harm, more specifically according to a recent study, by "disavowing the thug image of African American males" (Dow 2016, p. 161). In Dow's study, 60 mothers, from both the upper and middle classes, reported using four different strategies to manage their sons' "thug" image. They facilitated their sons' experiences in different environments in order to expose them to different cultures, subcultures, and communication styles. They managed the environment by guiding their sons' regular social interactions. These mothers were also engaged in minimizing their sons' images and emotions by encouraging or discouraging certain appearances/behaviors, such as "not allowing their sons to wear hoodies" or "making them join some relaxation classes to control their emotions during negative interactions with other peers or teachers in schools" (p. 181).

The goals of gender socialization of boys in African American families-to foster self-reliance and "mistrust" for others when it comes to displaying their masculinity-may be incongruent with their values of "community, communalism, and cooperation" (Howard et al. 2013, p. 227). The parents in the study encouraged their sons to avoid displaying masculinity and to stay away from other groups in order to protect themselves from harm. African American parents also reported using "barrier socialization", explaining to their children about the kinds of difficulties they might face due to a less positive evaluation of their race (Smalls and Cooper 2012). Along the same lines, this paper examines the different strategies Sikh parents use to socialize their boys.

\subsection{The Role of Popular Media in Framing Public Perception}

In addition to current events and news, the mass media deals with "social norms, customs, and standards ranging from behaviors to beauty" (Mok 1998, p. 185). The media contributes to shaping dominant narratives in public discourse, including attitudes toward immigrant and minority groups (Angeles 2010). According to Matin et al. (2008), the macro level factors such as media depictions and the sociopolitical environment interact with each other to stigmatize certain groups. In this paper, we 
refer popular media as mainstream news media, not the social media or other forms of mass media. When the media does not deliver an impartial, accurate or balanced picture of a particular group, the distorted impressions created are usually too powerful to be corrected by rational interpretation, especially when consumers have limited exposure to cultural diversity. For example, according to the Sikh American Legal Defense and Education Fund (SALDEF 2011), "on 6 May 2011, CNN and the Financial Times published online articles about Osama bin Laden using images of a Sikh to supplement the news stories. Both images were featured on the outlets' homepages and were likely viewed by millions of readers". The SALDEF made both outlets aware and managed to have the images removed after a few hours, but such misrepresentations often go unnoticed.

Biased media representation of a particular group leads to stereotyping. For example, media portrayal of Mexican immigrants crossing the borders without documentation causes some people to regard all Mexicans as "undocumented". Media portrayal of Asian Americans as a "model minority" engenders the view that "all" Asians perform well academically and professionally. Likewise, the association of crimes with African Americans and Latino Americans can shape racial attitudes towards these groups (Holt 2013). Media stereotypes often contribute to such prejudice and discrimination on the basis of gender, race, nationality, religious affiliation, and sexual orientation, for disadvantaged groups (Bennett 2000; Bush and Furnham 2013; Holt 2013; Mok 1998; Plakoyiannaki and Zotos 2009; Saracho and Spodek 2007). The media representation of Muslims has always been problematic. According to a meta-analysis of 345 studies conducted between 2000 and 2015, most studies on Muslims and Islam are conducted in the United States followed by United Kingdom, Australia, and Canada, all non-Muslim majority countries, from a "White man's" perspective and limited or no Muslim voices in them (Ahmed and Matthes 2017). The 9/11 attacks had exacerbated the already negative representation of Islam as an "irrationally violent, monolithic, homogenized, and sexist religion" and Muslims framed as "uncivilized, militants, terrorists, oppressing their women, and against us" (p. 4). There have been increased anti-Muslim sentiments since Donald Trump took the President's office, which has led to direct physical and verbal attacks on Muslims and other ethno-religious minorities including Sikhs. These attitudes against a certain group have strong implications for mental health and general well-being (Ewart and Kate 2018). Still this topic is missing from the academic conversations.

The media plays an important role shaping the racial attitudes of both children and adults. Ponterotto and Pedersen (1993) observed, "Children, adolescents, and adults develop perceptions of racial/ethnic groups consistent with the way members of these groups are portrayed (or not portrayed) in the media" (p. 32). Kromidas (2004) captured reactions to post-9/11 images of Muslims among a group of 8-9-year-olds in a New York City school. The children expressed bias and negativity, saying that Muslims "like money", "like to kill people", "don't talk English", "eat out of dirty pots", "are poor", "are terrorists", and "have long hair" (p. 20). Many children reported acquiring these ideas from media representations. In a recent study by Brown et al. (2017), these negative attitudes towards Muslims have not changed much. The U.S. children in the study did not consider Muslim children as Americans, based on their knowledge from media, unless they have prior contacts with Muslim children. In another study, Hussain (2010), a professor of theological studies, noted that when he asked college students about their perception of "Islam" in the months following 9/11, their typically negative perceptions were based on popular media images.

In all its modalities, the media enacts powerful public pedagogies that shape the social identities of children, family, gender, and race (Luke 1994, p. 340). This influence is manifested not only in prejudices and stereotypes, but also in the adaptive parenting practices of minority families as they try to protect their children and to help them navigate the world (García-Coll et al. 1996). According to a more recent study of Mexican parents, Cruz-Santiago and García (2011) noted that parents often use a combination of control and support strategies-i.e., adaptive parenting strategies-to protect their children from the dangers of society.

The fact that American popular media has often misrepresented Sikh men as terrorists because of their turbans and beards (Joshi 2006) has become an important context for Sikh parents in their 
ethno-religious socialization of their children. This paper addresses the following two research questions: (1) How do members of a small Midwestern Sikh community, particularly parents, perceive media portrayals of Muslims and Sikhs after 9/11?; (2) How do those perceptions shape the ethno-religious socialization of their children? In addition to popular United States media, we also examine how Sikh heritage media feature in parents' ethno-religious socialization of their children, especially boys.

\section{Methods}

The paper draws on data from a larger ethnographic study that investigated Sikh parental ethno-religious socialization practices in a Midwestern community in 2011-2012. The study consisted of more than $90 \mathrm{~h}$ of ethnographic fieldwork data and in-depth interviews with 23 Sikh parents (11 mothers and 12 fathers). For this paper, we draw on in-depth interview data regarding how Sikh parents perceive media portrayal of Sikhs and how these perceptions influence their ethno-religious socialization practices.

\subsection{Sikh Family Contexts}

The parents in this study are part of a small Sikh community (roughly 50 Sikh families) in a Midwestern town of about 116,000 (Lansing, Michigan population: Census 2010 Interactive Map, Demographics, Statistics, Quick Facts). In terms of migration history, nine out of the 12 male participants in the study first migrated to New York between 1984 and 1994 as adolescents or young adults. In many cases, their first jobs were as taxi drivers. Of these nine men, all but one traveled to India to marry Indian Sikh women; one married a Sikh woman whose parents had also migrated to NY from India. In the late 1990s, after starting their own families, they moved to a small Midwestern town where they had existing networks (e.g., extended family members, friends, someone from their Indian village) in place. When asked why they chose to move here, they mentioned a few more reasons: (1) Relatively good quality public schools in the area; (2) the close-knit Sikh community, where "they could live as if they were living in a small village in India"; (3) the opportunity to exercise social control, through ethno-religious community, in child rearing due to the small geographical area of the town; and, (4) many men in the community valued the ownership of convenience stores and viewed it as a sign of upward social mobility. Three of the male participants came directly to this Midwestern town because of pre-existing networks; they were married in India before migrating. The elderly members of the community founded the Gurdwara (Sikh temple) in 2004 to help families keep their children connected to their ethno-religious heritage. The community gathers every Sunday at Gurdwara for worship and community lunch, taking pride in sharing their food and culture with guests from different backgrounds.

\subsection{Access to the Community}

The first author, who is a native Hindi speaker, immersed herself in the community Gurdwara. There was some initial skepticism about her intentions, given that she was neither a Sikh nor a native Punjabi speaker, but she soon began building rapport with the community. She spent almost every Sunday for 10 months attending services, community lunches (known as langar), festivals, and community events. She earned the trust of community members by actively engaging in various services in the Gurdwara (known as Sewa, one of the values of Sikhism) such as starting a playgroup to involve young children in meaningful activities during the service, helping the women in the community kitchen, and tutoring young children. The first author is a native Hindi speaker from the state of Haryana in northern India, which is adjacent to Punjab. These existing linguistic ties between the two languages facilitated communication in this study. The second author, a Chinese American female, was the first author's dissertation advisor. 


\subsection{Participants}

The study was approved by the Institutional Review Board (IRB) at the first and second authors' university at the time of data collection. The participant selection criteria called for families who attended the Gurdwara frequently and who had at least one son between the ages of 10 and 18 . All but one of the participating families (one father was a widower) were two-parent families-a highly valued norm in Indian society (Singh 2011). Participants were asked to sign informed consent forms and culturally appropriate pseudonyms are used in our paper to protect their anonymity. "Singh", the last name for all male participants, and "Kaur", the last name for all female participants, have their origin in Sikh history. Sikhism originated with the idea of creating equality among its followers and protecting its people, especially women and children, from the atrocities of Muslim rulers. The uniform last name is grounded in the principle of equality. We use Singh and Kaur as last names and pseudonyms for first names. Table 1 presents the demographics of the participants.

Table 1. Demographics of the participants.

\begin{tabular}{ccc}
\hline Parents Characteristics & Father $(\mathbf{N}=\mathbf{1 2})$ & Mother $\mathbf{( N = 1 1 )}$ \\
\hline Mean Age (years) & $42(\mathrm{SD}=2.6)$ & $37(\mathrm{SD}=3.8)$ \\
\hline \multirow{2}{*}{ Education } & College graduates $=2$ & College graduates $=2$ \\
& High school $=7$ & Some college $=2$ \\
& High school $=4$ \\
& & High school dropouts $=3$ \\
\hline Occupation & Convenience Stores $=11$ & Holl timemakers $=4$ \\
& Auto insurance agent $=1 *$ & Half time convenience stores $=2$ \\
& Professional $=1$ & Hospital $=2$ \\
& & Professional $=1$ \\
\hline
\end{tabular}

* One father began working as an auto insurance agent in addition to owning a convenience store.

The mean ages of the fathers and mothers at the time of the interviews were 42 and 37 years, respectively. All but one of the men owned convenience stores, a common occupation in this community. Four women were homemakers, two worked full-time, and two half time, at their families' convenience stores; two worked at a local hospital and one was a professional.

The women and children attended the Gurdwara more frequently than the men, who were occupied at their convenience stores on Sundays. All convenience stores owned by the families were located in rough and distressed neighborhoods. Most participants in the study lived in three different neighborhoods, not where the stores were located. Two families lived in upper middle class, predominantly white and Asian neighborhoods. The other ten lived in middle $(\mathrm{N}=7)$ and lower class $(\mathrm{N}=3)$ neighborhoods along with other minority groups. The children of the community went to public schools in the area, where they interacted with children from other cultural and religious backgrounds. Since most men migrated to the United States as either adolescents or young adults and assumed work and family responsibilities early on, over half of them had no post-secondary education. At least four women had attended or graduated from college. Many of the fathers took pride in their economic prosperity though they were not asked about their income. National trends of occupation and education among the Sikh community are not noted in the literature. The 12 families that participated had a total of 35 children ( $2-4$ children per family): 25 males and 10 females aged 4 to 21 (mean age $=12.8$ years; $S D=4.65$ ). The home language was Punjabi. Children used Punjabi to communicate with their parents and other community members, but they spoke English to one another.

\subsection{Data Collection}

The first author gathered the data for this study. In all but two interviews, the questions were asked in Hindi and the answers were provided in Punjabi. On average, each interview lasted for about $45 \mathrm{~min}$. Parents were interviewed separately. Of the twelve fathers, five were interviewed in their 
homes and seven at their convenience stores. Ten of the eleven mothers were interviewed in their homes and one at the family's store. The topics covered in the interviews included immigration history, adaptation to the United States, parents'/grandparents' socialization goals, the Sikh religion and its role in child rearing, the role of the Sikh community in parenting/grandparenting, media images of Muslims and their impact on the Sikh community, and issues of racism and discrimination. The researcher's ongoing involvement in the community facilitated the development of culturally appropriate questions designed to elicit meaningful responses from the participants (Gallagher-Thompson et al. 2003). In addition to the interview data, we also draw on the first-author's extensive ethnographic fieldwork notes from conversations with community members and observations of interactions during Sunday services and community lunches, festivals, and functions.

\subsection{Data Analysis}

The interviews were recorded, transcribed, and translated into English. A native Punjabi speaker checked $30 \%$ of the transcripts to ensure the accuracy of transcription and translation and confirmed about $98 \%$ accuracy in translation. We addressed the $2 \%$ discrepancies by asking this person clarifying questions and reworking the transcripts. We used the qualitative software, Nvivo 9 to code the translated data.

Though she came from a similar background and geographical origin as the participants, the first author was still an outsider: Not a fluent Punjabi speaker, not a Sikh, and with a different migration history. Reflecting on how these characteristics might have affected the data analysis process helped eliminate personal bias. The first author, along with the third author (a native English speaker) coded the interview and ethnographic fieldwork data, identifying common themes related to the effects of media. Interview transcripts and relevant ethnographic field notes were reviewed several times to create tentative labels for open coding. Examples included "grandparents bringing literature for congregation" and "books and reading materials on Sikhs". For the axial coding, we identified relationships among the open codes, for example the relationship between the above two codes was labeled "cultural socialization". Following that, we determined core variables that encompassed most of the data in certain categories, a process known as selective coding. For example, The Role of Sikh Media in Ethno-religious Socialization. The process involved rereading data to group it under selective codes (Strauss and Corbin 1998). The authors met 3-4 times for 30-45 min each to check accuracy and consistency in coding. A Sikh professional, not from this community, was consulted to explain religious and cultural nuances in the manuscript, for example the historical context of the last names "Singh" and "Kaur".

\section{Findings}

Our analyses suggest that our participants were keenly aware of media misrepresentation and confusion of Sikhs and Muslims as well as elevated levels of hate crimes and discrimination after 9/11. The majority had elected to have their sons give up outward markers of religious identity in order to protect them. They also actively engaged in both community and personal efforts to educate the general public about their culture and religion and used Sikh media to socialize their children in their ethno-religious development. Below we present four major themes related to the role of popular media: (1) Parental identity markers, (2) parental decisions about their sons' identity markers, (3) parental strategies to counter mistaken identity representation in the wider community, and (4) the role of media in ethno-religious socialization of the children.

\subsection{Parental Identity Markers}

The interviewees explicitly addressed the connection between media images and their ethno-religious identity and expression thereof. For example, one of the participants said, "They [mainstream] have hard time differentiating between Sikhs and Muslims. And it is not their fault. Media portrays us all the same." After 9/11 and the ensuing media misrepresentation, many Sikh parents 
reported feeling set apart by their appearance, but endeavored to make sense of their experiences. This could be attributable to their resilience or to internalization of their experiences with discrimination. Amrit Singh, the father of two daughters and a son, commented, "Media made a big deal out of it ... you know there were some hatred crimes against Muslims and Sikhs and we look alike because we wear turbans like Arabs." Gurpreet Singh, the father of three sons, discussed increased surveillance at airports post 9/11:

After 9/11, it is just impossible to pass the security without having any hassles. In the beginning right after that, they would ask us to take out our turban, but these days, they just check without asking to take it off. However, if they suspect someone, then they make sure that the person takes off his turban. It is a problem, but I also believe that this is a safety issue. If I have to take off turban for officers to ensure safety for 700-1000 people traveling in day, why not?

The participants shared a wide variety of personal considerations with regard to their outward appearance. Amrit Singh reported that neither he nor his family had ever faced any problems though his discomfort after 9/11 caused him to cut his hair and change his appearance. He suggested that the media has exaggerated the hate crimes. Amrit Singh suggested that while Sikh immigrants in other areas may have faced increasing harassment and discrimination post $9 / 11$, he had not had problems in this small Midwestern city.

Others were affected more strongly. Praneet Kaur, a professional and mother of a boy and girl, was very conscious of her looks and wanted to stay away from "the typical media image of Sikhs." She also decided that her son would not grow his hair, as is traditional for both Sikh men and women. Males tie their hair in turbans and females wear braids, the former being more noticeable than the latter. Praneet shared,

Um, I am not the typical, traditional Sikh girl. I got my hair cut ... .I want to look good. Moreover, I do not want to look different than my colleagues. They have a typical mindset of how Sikhs look like through TV and other popular media. I want to debunk that. I don't want to make a pigtail every single day. So for me, I have my own values that I have to be respectful to other people in the house, and that's what I want them [my children] to know.

Interestingly, a number of parents had already made the decision to not retain outward religious markers even before 9/11 occurred. Jagdeep Singh, a professional with a son and a daughter, had internalized the negative connotations:

I used to have a turban till my college. I cut my hair just 6-7 months before coming to the United States. I also cut my beard after a year when I started working in [name of the American city] because I looked different, I spoke different and they were not just able to adjust with me and I assessed what was important. Was my beard so important? No ... I wanted to make myself comfortable working with them. I wanted myself to make appealable [sic] for them to be able to work with me.

Jagdeep Singh spoke in detail about the discrimination he had faced at work. He claimed on the one hand that not keeping the outward markers was his personal choice and not the result of prevalent media images, while admitting on the other hand that he made those choices because his colleagues were not comfortable with his appearance and accent. Some of the other fathers had cut their long hair and removed the turban before coming to the United States. There are several possible explanations for this phenomenon. Many fathers migrated to the United States after Hindu-Sikh riots erupted in India in 1984, following the assassination of Prime Minister Indira Gandhi by two of her Sikh bodyguards. The participants could conceivably have decided to camouflage their identities as they fled in search of asylum. The fear of persecution, anticipation of the unknown or of an unwelcoming reception in the new country or workplace, were all factors. 
Some parents changed their appearances and later reverted. In the wake of 9/11, Amrit Singh sought to differentiate his appearance from that of Arabs. However, when Dr. Manmohan Singh, a Sikh with turban and beard, became the Prime minister of India for two terms and brought Sikhs more positive visibility in the media, he reversed this decision. He said,

I had cut my hair. I was scared at the time when 9/11 happened. Many of our Sikh brothers were mistreated because these people [Americans] couldn't see us separately from Arabs. If you see Muslims in general, not all of them grow their hair or wear turban. But people watched those images on TV, the terrorists and Muslims. So I didn't want to grow [my hair] at that time. And now you know Manmohan Singh has been the prime minister of India for two terms. People in the world know who Sikhs are. So I have developed some confidence too (laughing).

\subsection{Parental Decisions about Their Sons' Identity Markers}

Fallout from media images of Muslims shaped the Sikhs' perceptions surrounding their identity markers, as well as their ethno-religious socialization goals appropriate to their children's retention of outward identity markers. A few families decided that their sons would keep their hair long $(\mathrm{N}=4)$, others did not want their young sons to grow their hair $(\mathrm{N}=3)$, and some decided to cut, or let their sons cut, their long hair after personal experiences of teasing or hearing about an incident in the community or through the media $(\mathrm{N}=5)$. In the words of Harpreet Singh, the father of three sons: "No, we decided not to keep turban for our boys. I have heard that there is some bullying and teasing with kids who wear patka (a form of small turban that boys wear), so why to put my children at risk of being teased and harassed." Praneet Kaur articulated similar views about wanting her son to fit in: "I don't expect him to grow his hair and wear patka. I want him to be as accommodating as possible-I don't want somebody to picking on him because he wears patka. You know what has happened in New York, in California, and at many other places after 2001. So I am okay without it." Along the same lines, Paramjeet Kaur, the mother of two sons and one daughter was very wary of having her sons grow their hair. The media images of hate crimes and bullying against Sikhs were so strong in her mind that she did not want to rely on the solutions offered by Sikh media:

No, we haven't had that restriction since their young age. You must know if we use pagdi (turban), they may be subjected to teasing and bullying in school because we are aware by media. Actually recently media, especially Sikh media, has started propagating that there is no such thing now in schools. Sikhs are free- they can wear turban and swords in school. But no, I don't believe it. Racism still occurs. We don't want to put our children at risk of racism-in school people may ask them, "Why are you wearing turban in school?" Our kids should not feel embarrassed because of those things.

Most parents were keenly aware of harassment incidents that occurred in other places through the popular media and expressed their strong desire to protect their children from these traumatic experiences. The parents who decided that their boys should keep the identity markers $(\mathrm{N}=4)$ articulated the importance of teaching their children the meaning of the markers so that they could educate their peers and teachers in school. The children who kept their turbans were younger than the ones who had cut their hair. One possible explanation is that younger children may not be as susceptible to bullying as older children. Another is that as children grow, they get more self-conscious about their looks and care more about fitting in with their peers. Moreover, older children might have more tools to resist the authority of their parents as they strive for autonomy. The more educated parents decided not to focus on outward markers as part of their sons' identity in first place. There is limited data regarding the degree to which this decision was affected by the media. 


\subsection{Parental Strategies to Counter Misidentification in the Wider Community}

The parents in the study used several strategies to counteract negative images and protect their children while helping to develop/maintain their positive ethno-religious identity. Participants also described their daily endeavors to educate people about Sikhism and to counteract media misrepresentations. Jagdeep Singh commented on interactions with his coworkers "Sometimes they ask if we are Muslims or Arabs. We tell them how different we are ... . We also tell them about the history of Sikhism if they dig deeper." Sukhvinder Singh, the father of two sons, shared the importance of clearing up any confusion that people may have. When asked why people confuse Sikhs with Muslims, he said,

Media. The world changes quickly when they see the things happening in the world. Some people used to ask after 9/11 attack because I wear this patka, but I think I never had trouble telling them that I was a Sikh from India.

Charanpreet Singh, the father of two sons and a daughter said, "Well [they do] not [ask] directly. Sometimes people ask about my headgear. I tell them. But after 9/11 happened, people used to ask me if I was a Middle Eastern or Arabic person." The interviewer: "How did you feel?" Charanpreet Singh: "I thought they were just curious. It is always good to clarify that for them rather than letting them keep wondering-you know what I mean." Jagdeep Singh, a professional, also talked at great length about the responsibility of educating people as to how he was different from Muslims and how Sikhism differs from Islam:

They ask me for sure. It comes from how I speak. I have a heavy Punjabi accent (laughing) and of course by my last name (Singh). I tell them who I am-I have to differentiate for them if I am a Hindu, Muslim, or Sikh. Many people don't have much exposure.

Not many parents reported visiting their children's schools other than to attend parent-teacher meetings. With two exceptions, the parents did not speak much about advocating for their children in their schools. This could be due to lack of education in the community. Sardeep Singh, the father of a son and a daughter, spoke of a certain professional who contributed to educating the wider community about Sikhism: "He would wear his turban and would go to each school and teach the children about Sikhism. He provided all the books on Sikhism in the [name of city] school libraries."

In an effort to reach out to the broader community, this Sikh community organizes a Sikh Parade every year around the time of the festival of Baisakhi in April, a spring harvest festival that marks the advent of new year in Sikh calendar. The community members invited the first author to the Sikh Day parade, an event that promotes awareness of the Sikh community. Amrit Singh shared the use of media in outreach, "We distribute books about Sikhism on the Sikh day parade. We also have lots of media coverage-newspaper, TV channels on that day." While Sikh parents and communities have suffered negative outcomes due to popular media confusion of them as Muslims, they also adopt media tools in their efforts to reach out and educate the public.

Interestingly, the Sikh community joined the protest in support of the Muslim community during an anti-Muslim event led by the Florida pastor, Terry Jones. The first author asked one of the participants what motivated the Sikh community to do so given that they usually struggle to differentiate themselves from Muslims. His response was, "This could happen to any one of us. If we stand by their side, they will stand by ours. Also the media would know that the Sikh community came forward to help the Muslim community. People would start understanding the difference better."

Overall, many fathers and community members took responsibility for educating the wider community about Sikhism and tried to prevent misidentification of Sikhs as Muslims in everyday life. This effort to differentiate themselves, as mentioned previously, was not the result of anti-Muslim sentiment. 


\subsection{The Role of Media in the Ethno-Religious Socialization of Children}

The parents identified the Sikh community and media as important means of ethno-religious socialization. Mothers were generally more active in connecting their children with the Gurdwara, with the support of the fathers who articulated the importance of connecting their sons to the wider Sikh community; they also valued the elderly and "wise" community members helping youth navigate the history of the Sikh religion. Parents also used transnational news to keep themselves abreast of what was happening overseas. The constant comparison of Sikh youth in India with those growing up in the United States emerged as a salient subtheme.

\subsection{Cultural Socialization}

Parents reported using various forms of media to teach and retain the Punjabi language. Some bring Punjabi religious literature from the Gurdwara to teach their children Gurmukhi (a system of writing the Punjabi language). Others subscribe to Indian television channels. Praneet Kaur used audiotapes to teach her children about religion,

This morning, I played "Japu ji Sahib path" on tape for the first time ever. This tape had translation of Japu ji sahib path in English. And it tells you a practical way of living your life. And [name of son] came and he sat there with me and he listened to it very carefully. And those are exactly the things that I would like him to get from our religion.

The parents also shared that attending Gurdwara every Sunday with their children and listening to the Punjabi hymns sung by the priest also play an important role by encouraging the children to ask questions. In the Gurdwara, the management screens English translations of the Punjabi hymns so that the children can decipher their meaning. The Gurdwara also maintains a library of Punjabi books and religious scriptures for children.

\subsection{Global Awareness}

The media also helps parents keep abreast of changes in their native Indian communities and thus influences their ethno-religious socialization decisions. Some fathers compared their children with youth growing up in India. Tejpreet Singh, father of two sons and a daughter, talked at length about drug addiction problems among youth in India.

Oh yes, it has been a big news on lots of channel recently. And kids in India these days are not that respectful as we used to when we were growing up. We are losing the values of respect there. We have more of these values here.

Sukhvinder Singh, the father of two boys, added:

The youth in India are cutting their hair. If you watch television or read newspaper, you will see lot of them without turban now. Also these [American] people often do not understand who we are. So why bother [keeping outward identity markers]?

In conclusion, parents used various media sources to educate their children about the ethno-religious practices of Sikhism. The parents shared that they used Indian media to keep themselves updated on religious and cultural life in India.

\section{Discussion}

The experiences of Sikh communities and families have changed drastically since 9/11. They have been subjected to elevated levels of hate crimes rooted in media misrepresentation of them as Muslims. Even though Sikhs have been mistaken as Muslims and their children, especially boys, have faced bullying and discrimination, we want to emphasize that it is not okay to direct the violence and animus towards Muslim children. In this study, we examine how Sikh immigrant parents in one community 
respond as they socialize their children, especially sons who stand out because of their outward identity markers, in this new environment. Our findings show that post 9/11, Sikh parents used adaptive parenting strategies to protect their sons from potential harm (Cruz-Santiago and García 2011; Dow 2016; García-Coll et al. 1996). While most parents in the study did not feel directly affected by media images of Muslims and the subsequent misidentification of Sikhs, media and the social environment do play an important role in their own identity as well as their ethno-religious socialization of their children. Keenly aware of the potential danger their sons may face due to media misrepresentation and report of hate crimes, the majority of parents in our study decided to encourage their sons to relinquish outward identity markers such as long hair worn in a turban. Our results confirm previous research findings on the experiences of Sikhs after 9/11 (Ahluwalia and Pellettiere 2010; Verma 2005). Many parents in the study focused on inculcating the Sikh values of service, respect, and equality by visiting the Gurdwara frequently for cultural and linguistic enculturation for their children. Our study also makes a number of important contributions to studies on immigrant and minority parent socialization. First, most studies on parent socialization have focused on ethnic-racial socialization (Hughes 2003; Hughes et al. 2006). Few studies have examined immigrant parents' ethno-religious socialization of their children (Inman et al. 2007; Umaña-Taylor and Fine 2004; Yoon 2004). Still fewer studies have focused on the role of both mainstream and immigrant heritage media in parental socialization. Drawing on intensive ethnographic fieldwork and in-depth interviews with members of one Midwestern Sikh community, we documented parental responses to media misrepresentation and how they shape their ethno-religious socialization of their children. Previous studies have not examined the relationship between popular media and socialization. Dow (2016) study on African American parents' attempts boys to debunk the image of "thug" through socialization confirms that the media can exacerbate negative images of certain groups, causing parents to take responsibility for protecting them from harm. Our study is an important contribution to literature on the socialization of minority boys. It also considers the important construct of ethno-religious socialization, which is understudied.

The findings suggest that parental background, including education, gender, occupation, and social cognition-beliefs, perceptions, attitudes, and expectations-affects their socialization efforts (Okagaki and Bingham 2005). Only four of the twelve families decided to keep their children's outward markers. The decision was influenced by their own experiences as well as awareness of trends in India. Parental socialization was a combination of proactive (i.e., preparing children in anticipation of prejudices) and reactive (i.e., taking action after the child has encountered the prejudice) and covert and overt strategies (Hughes et al. 2006; Umaña-Taylor and Fine 2004). Only a few parents ( $\mathrm{N}=2$ ) were able to advocate for their children in schools or to educate others about their ethno-religious practices in schools. This could be a function of lack of education and language skills. Moreover, parents who were more educated decided not to focus on outward markers as part of their sons' outward identity markers in the first place. This decision could be attributed to fear of more discrimination, internalization of discrimination, or their own conscious efforts to assimilate (Caughy et al. 2002).

There were no reported gender differences in how mothers and fathers perceived media images, though mothers took a more active role in bringing their children to the Gurdwara and fathers reported a more active role in protecting their sons from potential bias and connecting them to the wider Sikh community. Since boys and men are more vulnerable to bullying and discrimination due to their outward identity markers, the focus of this study was ethno-religious socialization of boys.

Our findings also show that racism against Sikh children and families existed before 9/11. When these Sikh families moved to the small Midwestern town from NYC in the 1990s, there was little awareness of the Sikh faith in the area; many children in the Sikh community were teased and bullied based on their outward identity markers. After 9/11, things intensified. The confluence of media news and lack of awareness in the broader US community has shaped Sikh parents' ideologies that are appropriate to their children's retention of outward identity markers and their attempts to protect their children from bigotry. We collected this data in 2011-2012. We could only speculate that 
anti-immigrant and anti-minority religions sentiments have only intensified since the enactment of Trump's anti-immigrant policies and his anti-Muslim agenda.

Our findings also show that the Sikh community and media played important roles in parents' ethno-religious socialization practices (Bronfenbrenner 1979). The Gurdwara helped the families in their socialization goals by providing a niche for cultural and linguistic resources, religious history, and support from community members, a form of community cultural wealth (Kurien 2014; Yosso 2005). The community used educated advocates to represent their group; the annual Sikh Day parade was one of the means of educating the broader community about Sikhism. The community also supported Muslims by participating in a protest against an anti-Muslim event in the area to demonstrate solidarity against racism, discrimination, and "otherization". The Sikh media served as a means of support for parental cultural socialization and an antidote to the images of Muslims (or Sikhs mistaken for Muslims) as they appear in the popular media.

The media images of "9/11 terrorists" were very powerful and led people, primarily nationalists who had limited interactions with Sikh and Muslim communities, to label anyone with a turban and beard as "a terrorist". Instances of bullying that parents were aware of included young boys being teased as girls and older boys being confused with Muslims and called "terrorists" (Verma 2005). When the media does not present balanced portrayals of a particular racial or ethnic group-positive and negative, strengths and weaknesses, triumphs and losses-the consumers often make incorrect inferences. The group that becomes the target of this biased portrayal or oppression has to assume responsibility for educating others and debunking stereotypes. Even though most participants in the study responded by giving their experiences a positive spin, many seemed to have internalized them. Negative messages about different groups can create profound implicit and explicit bias among children; these stereotypes are often solidified by media portrayal of those groups (Killen and Rutland 2011). This "education about self" process, especially when it comes to the debunking of stereotypes, could put additional pressure on members of a minority group. Sikhs often seek out their families, communities, and faith to help cope with the discrimination they face due to mistaken identity (Ahluwalia and Pellettiere 2010; Hall 2002).

Social representations can become personal representations and affect the content and values that constitute one's identity. This can pose a threat to identity development among minority communities and their members, which in turn may affect coping strategies employed by the victims (Jaspal and Cinnirella 2010). Many ethnoreligious minority group members face discrimination at various levels: Individual, institutional, and cultural (Kumar 2016). Additionally, media representations and negative stereotypes of particular groups (e.g., portraying African Americans as "violent and aggressive", associating Muslims with "terrorist activities", depicting Asians as "model minorities") may threaten identity formation process in these groups (Riek et al. 2006). It is of the utmost importance to present balanced and fair social representations of different racial, ethnic, religious, national groups, and gender and sexual orientations; it is also imperative to avoid "otherization" of certain groups. Adults can play an important role in mitigating the effects of biased media representations and schools can support their students by creating environments that are more inclusive and (re)educating while debunking stereotypical representations.

The media can also be beneficial to immigrant and minority communities. For example, in the present study, the parents used Sikh media to socialize their children in their religion and culture to help them form their ethno-religious identities. The mothers used various ways of teaching their children about Gurus and the history of Sikhism-audio recordings, translated audio and videotapes, storytelling, Punjabi TV channels, and translated religious scripts. The grandparents who traveled often to India brought English books about Sikhism to the Gurdwara library so that children could borrow them.

Our study has a number of limitations. First, it only presents parents' and community members' views; the youth's views on media, parental ethno-religious socialization, and their effects on identity are not included. It is important for future research to examine how Sikh youth themselves perceive 
media portrayal and parental socialization efforts and construct their ethno-religious identities. Second, findings from this study cannot be generalized to other Sikh communities in the US. The small Midwestern Sikh community in our study had limited members and resources. The scenario might have been different in other Sikh communities with greater resources in urban areas where large number of immigrants settle. It is important for future research to continue to examine the role of diverse communities in supporting parental socialization.

Despite these limitations, our study demonstrates that media representations are an important factor in ethno-religious socialization, one that is overlooked in extant studies on immigrant and minority parental socialization. Our study contributes to the family socialization literature regarding parental decision-making, ethno-religious socialization, influence of the media, identity and discrimination, racism and stereotyping based on race, class, gender, ethnicity, and religion. To the best of our knowledge, this is the first study of ethno-religious socialization conducted in a Sikh community with a focus on popular media's effects on adaptive parenting. Our study also adds to the limited number of studies done with children of Sikh immigrant families, a group that is experiencing elevated levels of racism and hate crimes. We also believe that this study could be replicated with Muslim parents' socialization of their children in the face of negative portrayal of "Muslims" in media. According to The Association of Religious Data Archives (2010). estimates, there are more than four million Muslims in the United States. We need more studies on parent socialization and adaptations in other ethno-religious minority families.

\section{Implications}

Biased media portrayals of different groups (on the basis of social constructs such as race, gender, sexuality, etc.) can have long-lasting impressions, particularly on young minds. Negative images and attitudes may make members of a certain group feel unsafe and alienated to the point of compromising their mental health. In such circumstances, ethno-religious families and communities sometimes make adaptive compromises in order to protect their children. Accurate representations of people and communities are vital to the promotion of critical thinking. There is a need for safe spaces within which open analytical discussions about sensitive issues can take place with all sides of the issue represented. Media-focused research would do well to direct its efforts at examining the role of biased messages, their tone and frequency, in the creation of stereotypes and thus foster judicious consumption of information.

Adults can help by being positive role models for children and teaching young minds to be more accepting of diversity and difference while working together to establish common ground. Elementary school teachers can make a conscious effort to welcome home cultures into their classrooms through the choice of material. Teachers in higher grades can offer topics for class projects and presentations that address the differences, including media portrayal of minorities. Mental health professionals should be aware of different media portrayals of diverse groups of people and the possibility that their clients may have internalized popular images in order to understand their identity and mental health discourse (Mok 1998). These efforts are especially important in the current socio-political environment of the United States in which Islamophobia, xenophobia, and bigotry are prevalent.

Stress caused by otherization, stigmatization, and stereotyping may take mental and physical tolls on the health of minority families. White mainstream families do not have to think about the racial socialization of their children. Unlike many ethno-religious minority groups, White families do not have to go through the constant loyalty test-that they could be Sikhs or Muslims and Americans at the same time. Macro level influences, such as Islamophobia, mistaken identities, bigotry, and negative portrayal of ethno-religious minority affect family dynamics and ethno-religious identity formation of youth. We know that if someone is under constant stress, the Hypothalamic-Pituitary-Adrenal axis, our bodies' stress response, is overly stimulated and releases unhealthy amounts of cortisol that can result in health problems. Even though the Sikh parents in our study, especially fathers, took active roles in teaching the wider community about their ethno-religious practices, this ongoing responsibility 
to educate people about their culture and religion might exacerbate the stress on their families. It is important to understand the ethno-religious practices of the group to provide culturally appropriate tools for healing. The study has implications for other ethno-religious minority groups.

Author Contributions: For this research article, each authors' contributions included: M.R. was responsible for the conceptualization, methodology, software, validation, formal analysis, investigation, resources, data curation, writing the original draft, review and editing, and supervision of the Undergraduate Assistant (C.V.-G.). D.B.Q., who supervised M.R.'s doctoral dissertation, contributed to the conceptualization, methodology and review and editing for this manuscript. C.V.-G., the undergraduate Assistant at the time of preparation of this manuscript contributed to literature review, formal analysis, and validation of data findings.

Funding: This research received no external funding.

Acknowledgments: We would like to thank Janine Woolfson for meticulously editing many versions of this manuscript. Thanks to all the participants for sharing their stories with us, of courage and vulnerability, as immigrant parents in socializing their sons in Sikh faith. Sincere appreciation to our cultural consultants, Praneet Randhawa, Assistant Professor, Department of Marketing and Entrepreneurship, University of Baltimore and Manohar Singh, Dean, Southern Connecticut State University, for sharing their insights on Sikhism and Punjabi language and culture.

Conflicts of Interest: The authors declare no conflict of interest.

\section{References}

Abbas, Tahir. 2004. After 9/11: British South Asian Muslims, islamophobia, multiculturalism, and the state. The American Journal of Islamic Social Sciences 21: 26-38.

Ahluwalia, Muninder K., and Laura Pellettiere. 2010. Sikh men post-9/11: Misidentification, discrimination, and coping. Asian American Journal of Psychology 1: 303-14. [CrossRef]

Ahmed, Saifuddin, and Jörg Matthes. 2017. Media representation of Muslims and Islam from 2000 to 2015 : A meta-analysis. International Communication Gazette 79: 219-44. [CrossRef]

Angeles, Vivienne S. M. 2010. Moros in the media and beyond: Representations of Philippine Muslims. Contemporary Islam 4: 29-53. [CrossRef]

Bennett, Lisa. 2000. Fifty years of prejudice in media. The Gay and Lesbian Review Worldwide 7: 30-35.

Berry, John W., and David L. Sam. 1997. Acculturation and adaptation. In Handbook of Cross-Cultural Psychology. Edited by John W. Berry, Marshall H. Segall and Cigdem Kagitcibasi. Boston: Ally \& Bacon, vol. 3, pp. 291-326.

Bronfenbrenner, Urie. 1979. The Ecology of Human Development: Experiments by Nature and Design. Cambridge: Harvard University Press.

Brown, Christia Spears, Ali Hadeel, Ellen A. Stone, and Jennifer A. Jewell. 2017. U.S. Children's Stereotypes and Prejudicial Attitudes toward Arab Muslims. British Journal of Educational Psychology 17: 60-83. [CrossRef]

Bush, Bianca, and Adrian Furnham. 2013. Gender Jenga: The role of advertising in gender stereotypes within educational and non-educational games. Young Consumers 14: 216-29. [CrossRef]

Caughy, Margaret O’Brien, Patricia J. O'Campo, Randolph Suzanne M., and Kim Nickerson. 2002. The influence of racial socialization practices on the cognitive and behavioral competence of African American preschoolers. Child Development 73: 1611-25. [CrossRef]

Lansing, Michigan population: Census 2010 Interactive Map, Demographics, Statistics, Quick Facts. Available online: https://www.census.gov/quickfacts/fact/table/lansingcitymichigan/POP010210\#POP010210 (accessed on 11 October 2019).

Crossette, Barbara. 2004. India's Sikhs: Waiting for justice. World Policy Journal 21: 70-78. [CrossRef]

Cruz-Santiago, M., and Jorge I. Ramirez García. 2011. "Hay Que Ponerse en los Zapatos del Joven": Adaptive parenting of adolescent children among Mexican-American parents residing in a dangerous neighborhood. Family Process 50: 92-114. [CrossRef]

Dow, Dawn Marie. 2016. The deadly challenges of raising African American boys: Navigating the controlling image of the "thug". Gender \& Society 30: 161-88.

Dubensky, Joyce S. 2015. When Vaisakhi is more than a holiday. Tanenbaum: Combating Religious Prejudice. April 30. Available online: https://tanenbaum.org/blog/2015/04/7695/ (accessed on 11 October 2019). 
Ewart, Jacqui, and O’Donnell Kate. 2018. Reporting Islam: International Best Practice for Journalists. Abingdon: Routledge.

Ferguson, Gail M., Catherine L. Costigan, Christy V. Clarke, and Julianna S. Ge. 2016. Introducing remote acculturation: Learning your heritage culture from afar. Child Development Perspectives 10: 166-71. [CrossRef]

Gallagher-Thompson, Dolores, Nancy Solano, David Coon, and Patricia Areán. 2003. Recruitment and retention of Latino dementia family caregivers in intervention research: Issues to face, lessons to learn. The Gerontologist 43: 45-51. [CrossRef] [PubMed]

García-Coll, Cynthia García, Gontran Lamberty, Renee Jenkins, Harriet Pipes McAdoo, Keith Crnic, Barbara Hanna Wasik, and Heidie Vázquez García. 1996. An integrative model for the study of developmental competencies in minority children. Child Development 67: 1891-914. [CrossRef] [PubMed]

Gast, Phil. 2012. Wisconsin temple shooting victims: Putting others first. Cable News Network (CNN). August 7. Available online: https://www.cnn.com/2012/08/06/us/wisconsin-shooting-victims/index.html (accessed on 11 October 2019).

Gibson, Margaret A. 1989. Accommodation without Assimilation: Sikh Immigrants in an American High School. New York: Cornell University Press.

Guru Nanak Mission. 2008. Who Are Sikhs? Miami: Guru Nanak Dev Mission, Inc.

Hall, Kathleen D. 2002. Lives in Translation: Sikh Youth as British Citizens. Philadelphia: University of Pennsylvania Press.

Holt, Lanier Frush. 2013. Writing the wrong: Can counter-stereotypes offset negative media messages about African Americans? Journalism and Mass Communication Quarterly 90: 108-25. [CrossRef]

Howard, Lionel C., Jason C. Rose, and Oscar A. Barbarin. 2013. Raising African American boys: An exploration of gender and racial socialization practices. American Journal of Orthopsychiatry 83: 218-30. [CrossRef] [PubMed]

Hughes, Diane. 2003. Correlates of African American and Latino parents' messages to children about ethnicity and race: A comparative study of racial socialization. American Journal of Community Psychology 31: 15-33. [CrossRef]

Hughes, Diane, James Rodriguez, Emilie P. Smith, Deborah J. Johnson, Howard C. Stevenson, and Paul Spicer. 2006. Parents' ethnic-racial socialization practices: A review of research and directions for future study. Developmental Psychology 42: 747-70. [CrossRef]

Hussain, Amir. 2010. (Re) presenting: Muslims on North American television. Contemporary Islam 4: 55-75. [CrossRef]

Inman, Arpana G., Erin E. Howard, Robin L. Beaumont, and Jessica A. Walker. 2007. Cultural transmission: Influence of contextual factors in Asian Indian immigrant parents' experiences. Journal of Counseling Psychology 54: 93-100. [CrossRef]

Jaspal, Rusi, and Marco Cinnirella. 2010. Media representations of British Muslims and hybridized threats to identity. Contemporary Islam 4: 289-310. [CrossRef]

Joshi, Khyati Y. 2006. The racialization of Hinduism, Islam, and Sikhism in the United States. Equity and Excellence in Education 39: 211-26. [CrossRef]

Killen, Melanie, and Adam Rutland. 2011. Children and Social Exclusion: Morality, Prejudice, and Group Identity. New York: Wiley/Blackwell Publishers.

Kromidas, Maria. 2004. Learning war/Learning race: Fourth-grade students in the aftermath of September 11th in New York City. Critique of Anthropology 24: 15-33. [CrossRef]

Kumar, Tracey. 2016. "How do you know he's not a terrorist?" Examining microaggressions against people of South Asian descent. Multicultural Education 24: 12-18.

Kurien, Prema. 2014. Immigration, community formation, political incorporation, and why religion matters: Migration and settlement patterns of the Indian diaspora. Sociology of Religion 75: 524-36. [CrossRef]

Le, Phuong. 2017. Police to investigate shooting of Sikh man near Seattle as a hate crime. Chicago Tribune. March 5. Available online: https://www.chicagotribune.com/nation-world/ct-sikh-shooting-20170305-story. html (accessed on 11 October 2019). 
Luke, Carmen. 1994. Childhood and parenting in popular culture. Journal of Sociology 30: 289-302. [CrossRef]

Mann, Gurinder S. 2006. Making home abroad: Sikhs in the United States. In A Nation of Religions: The Politics of Pluralism in Multireligious America. Edited by Stephen Prothero. Chapel Hill: The University of North Carolina Press, pp. 160-80.

Matin, Jack K., Annie Lang, and Sigrun Olafsdottir. 2008. Rethinking theoretical approaches to stigma: A framework integrating normative influences on stigma (FINIS). Social Science Medicine 67: 431-40.

Mok, Teresa A. 1998. Getting the message: Media images and stereotypes and their effects on Asian Americans. Cultural Diversity and Mental Health 4: 185-202. [CrossRef]

Okagaki, Lynn, and Gary E. Bingham. 2005. Parents' social cognitions and their parenting behaviors. In Ecological Perspective on Parenting, 2nd ed. Edited by Tom Luster and Lynn Okagaki. Hillsdale: Lawrence Erlbaum Associates, pp. 3-33.

Pew Forum. 2012. The Global Religious Landscape: A Report on the Size and Distribution of the World's Major Religious Groups as of 2010. Available online: http://www.pewforum.org/global-religious-landscape.aspx (accessed on 25 September 2019).

Plakoyiannaki, Emmanuella, and Yorgos Zotos. 2009. Female role stereotypes in print advertising: Identifying associations with magazines and product categories. European Journal of Marketing 43: 1411-34. [CrossRef]

Ponterotto, Joseph G., and Paul B. Pedersen. 1993. Preventing Prejudice. Newbury Park: Sage.

Puar, Jasbir K., and Amit S. Rai. 2002. The remaking of a model minority: Perverse projectiles under the specter of (counter) terrorism. Social Text 22: 75-105. [CrossRef]

Riek, Blake M., Eric W. Mania, and Samuel L. Gaertner. 2006. Intergroup threat and outgroup attitudes: A meta-analytic review. Personality and Social Psychology Review 10: 336-53. [CrossRef] [PubMed]

Romero, Andrea J., Israel Cuéllar, and Robert E. Roberts. 2000. Ethnocultural variables and attitudes toward cultural socialization of children. Journal of Community Psychology 28: 79-89. [CrossRef]

SALDEF. 2011. Major News Outlets Remove Image Linking Sikhs to Osama Bin Laden. Available online: http://saldef.org/news/cnnandftimage/\#.WDKn67Lx7IU (accessed on 25 September 2019).

Saracho, Olivia N., and Bernard Spodek. 2007. Challenging the stereotypes of Mexican American fathers. Early Childhood Education Journal 35: 223-31. [CrossRef]

Singh, Bal Ram. 2011. Indian Family System: The Concepts, Practices and Current Relevance. New Delhi: D. K. Printworld Pvt. Ltd.

Smalls, Ciara, and Shauna M. Cooper. 2012. Racial group regard, barrier socialization, and African American adolescents' engagement: Patterns and processes by gender. Journal of Adolescence 35: 887-97. [CrossRef] [PubMed]

Stout, Harry S. 1975. Ethnicity: The vital center of religion in America. Ethnicity 2: 204-24.

Strauss, Anselm, and Juliet Corbin. 1998. Basics of Qualitative Research: Techniques and Procedures for Developing Grounded Theory, 2nd ed. Thousand Oaks: Sage.

Sunar, Lütfi. 2017. The long history of Islam as a collective "other" of the west and the rise of Islamophobia in the U.S. after Trump. Insight Turkey 19: 35-51. [CrossRef]

The Association of Religious Data Archives. 2010. Sikhs in the United States. Available online: http://www. thearda.com/QL2010/QuickList_113.asp (accessed on 11 October 2019).

The Pluralism Project. 2013. Post 9/11 Hate Crime Trends: Muslims, Sikhs, Hindus and Jews in the U.S. Harvard University. Available online: http://pluralism.org/research-report/post-9-11-hate-crime-trends-muslimssikhs-hindus-and-jews-in-the-u-s/ (accessed on 11 October 2019).

The Sikh Coalition. 2014. "Go home terrorist": A Report on Bullying against Sikh American School Children. March 1. Available online: https://www.sikhcoalition.org/resources/go-home-terrorist-a-report-on-thebullying-of-sikh-american-school-children/ (accessed on 11 October 2019).

Umaña-Taylor, Adriana J., and Mark A. Fine. 2004. Examining ethnic identity among Mexican-origin adolescents living in the United States. Hispanic Journal of Behavioral Sciences 26: 36-59. [CrossRef]

Umaña-Taylor, Adriana J., Katharine H. Zeiders, and Kimberly A. Updegraff. 2013. Family ethnic socialization and ethnic identity: A family-driven, youth-driven, or reciprocal process? Journal of Family Psychology 27: 137-46. [CrossRef]

Verma, Rita. 2005. Dialogues about 9/11, the media and race: Lessons from a secondary classroom. Radical Teacher 74: $12-16$. 
Yoon, Dong Pil. 2004. Intercountry adoption: The importance of ethnic socialization and subjective well-being for Korean-born adopted children. Journal of Ethnic and Cultural Diversity in Social Work 13: 71-89. [CrossRef]

Yosso, Tara J. 2005. Whose culture has capital? A critical race theory discussion of community cultural wealth. Race Ethnicity and Education 8: 69-91. [CrossRef]

(c) (1)

(C) 2019 by the authors. Licensee MDPI, Basel, Switzerland. This article is an open access article distributed under the terms and conditions of the Creative Commons Attribution (CC BY) license (http://creativecommons.org/licenses/by/4.0/). 